\title{
Determination of the characteristic sensory profiles of Aloreña table-olive
}

\author{
By H. Galán-Soldevilla ${ }^{\bowtie}$, P. Ruiz Pérez-Cacho and J.A. Hernández Campuzano
}

Universidad de Córdoba. Laboratorio de Estudios Sensoriales. Departamento de Bromatología y Tecnología de los Alimentos. Campus de Rabanales-Edificio Darwin. 14070 Córdoba (Spain)

Corresponding author: bt1gasoh@uco.es

\section{RESUMEN}

Determinación de los perfiles sensoriales característicos de la aceituna Aloreña

La aceituna Aloreña es una variedad de aceituna de mesa autóctona de la comarca del Valle del Guadalhorce (Málaga, España) que posee unas características propias que la distingue del resto de variedades, siendo las propiedades sensoriales las que mejor la diferencian. Para estudiar los atributos sensoriales que mejor definen a los tres tipos de elaboración de la aceituna Aloreña (verdes frescas, tradicionales y curadas) se utiliza la técnica del perfil sensorial. La selección de atributos sensoriales se realiza mediante discusión grupal en mesa redonda y utilizando análisis multivariante. Los datos obtenidos de los perfiles sensoriales se analizan utilizando un modelo mixto de análisis de la varianza (anidado $x$ factorial) y un análisis canónico. Los resultados del análisis de varianza indican que las principales diferencias entre estilos de elaboración se deben a los atributos frutado, sabor amargo y firmeza $(p<0.05)$ y que las diferencias entre muestras, dentro de cada estilo de elaboración, se deben a todos los atributos estudiados $(p<0.001)$. El test de medias de Duncan y el análisis canónico muestran que todas las muestras son diferentes dentro de cada estilo de elaboración.

PALABRAS CLAVE: Aceituna de mesa - Análisis descriptivo - Atributos sensoriales - Vocabulario sensorial.

\section{SUMMARY}

Determination of the characteristic sensory profiles of Aloreña table-olive

Aloreña olives are unique to and typical of the Guadalhorce region (Málaga, Spain). They possess some specific characteristics which make them an excellent product that is differentiated from the other olive varieties. The sensory profile technique was used to study the sensory attributes which best characterize the three processing styles of Aloreña table-olives. The characteristic descriptors are identified according to the round-table method and multivariate analysis. Sensory profile data obtained were analyzed using a mix of Nested Design ANOVA and Factorial ANOVA and by a canonical analysis. The effect of the factor processing style was significant only for three descriptors: fruit odor, bitter taste and firmness $(p<0.05)$ whereas the effect of the samples nested in each processing style was significant for all the attributes $(p<0.001)$. Duncan's post hoc test and the canonical analysis showed that all samples were different within each processing style.

KEY-WORDS: Descriptive analysis - Olive fruit - Sensory attributes - Sensory lexicon.

\section{INTRODUCTION}

Aloreña table-olives are seasoned cracked olives of the Aloreña variety that conserve their stone intact and are attached to the stalk. Their external color is usually green, greenish-yellow or light brown, depending on their degree of fermentation. They have a crunchy texture and a bitter taste, making them especially distinctive from the seasoned olives prepared from other varieties. They are characterized by the presence of a low level of oleuropein (the bitter component of the olive) that does not need any treatment with sodium hydroxide to sweeten it, and by the typical local products contained in the seasoning like fennel, thyme, garlic and peppers (Arroyo-López et al., 2008a). There are three different processing styles of Aloreña tableolives: fresh green olives, traditional olives and cured olives (BOJA no 215, 2009/11/04). Aloreña olives are unique to and typical of the Guadalhorce region (Málaga, Spain). This area includes a total of 19 municipalities spread between the Sierra de las Nieves and the Guadalhorce Valley. This valley, surrounded by a group of mountains in the north and slightly influenced by the sea, has unique climatic characteristics which have promoted this variety's quality.

Although sensory characteristics are determinant in defining a foodstuff, sensory studies concerning table olives are scant (Kanavouras et al., 2005; Panagou et al., 2006; Gonzalez et al., 2007; Marsilio et al., 2008; Aponte et al., 2010; Lanza et al., 2010; Valencic et al., 2010). The use of these sensory profiles may contribute to the identity of Aloreña olives by means of a sensory quality certification (Scintu del Caro et al., 2010).

The first step involved in generating a sensory profile is to develop a wide number of relevant descriptive terms. Once the initial list of vocabulary has been generated, the selection of the main descriptors must be performed. Multivariate techniques have been used for selecting the relevant descriptive terms that can differentiate among products. In a following step, a definition of each descriptor will be given and a suitable reference product will also be assigned to each of these descriptors. Once the panel has assimilated 
all the perceptions associated with the descriptors and is capable of quantifying the perception in relation to reference product, a sensory profile can be established (ISO 1994; Barcenas et al., 1999; Drake et al., 2001; Galán-Soldevilla et al., 2005; Pérez-Cacho et al., 2005).

The aim of this study was to establish the sensory profiles of the three processing styles of Aloreña table-olives in order to obtain a certified product (PDO Aloreña olives from Malaga). A lexicon (terms, definitions and references) for describing the odor, texture and flavor of Aloreña table-olives is also provided.

\section{MATERIAL AND METHODS}

\subsection{Samples}

\subsubsection{Table-olives used in the generation and selection of the sensory attributes}

Aloreña table-olives (fresh green, traditional and cured olives) were provided by local producers during the 2006/2007 growing season. A series of samples of Aloreña olives that display the most important specific characteristics was tasted in order to obtain the characteristic sensory profiles.

The olive samples were taken directly from commercial containers and placed in normalized tasting glasses (IOOC 1987) each with a minimum of 5 olives covered in brine from which the seasonings were previously removed. The glasses were covered with watch glasses and kept closed for at least 1 hour at room temperature before tasting. Mineral water was used for mouth rinsing between each sample.

\subsubsection{Table-olives used in the sensory profile}

For the sensory profile, 15 different Aloreña extra or first grade table-olives (IOOC 2004) from the 2009/10 growing season of the three processing styles were analyzed: 7 fresh green olives, 4 traditional olives and 4 cured olives.

\subsection{Sensory characterization}

\subsubsection{Generation and selection of the sensory attributes}

The procedure followed to obtain the vocabulary is based on ISO standards (ISO 1994; ISO 2003). Nine sessions of 1 to 2 hours each were conducted in order to develop the sensory profile: 5 preliminary ones were held to establish the test conditions and to generate and define the vocabulary and 4 sessions for the selection of the lexicon. Four to five samples, labeled with 3-digit random numbers were served, one-at-a-time, over a session. Samples were randomly allotted to sessions.

The sensory terms were generated individually by the assessors in the tasting booths using the "unguided free selection" technique (Guerrero 1999; Pérez-Cacho et al., 2005) and the sensory attributes were selected in accordance with ISO (1994).

The data were analyzed using Statistica 8.0 (StatSoft, Inc., Tulsa, OK USA). Principal Component Analysis (PCA) was used to reduce the number of attributes and the sensory profile sheet for the sensory analysis of table-olives was made. Finally, the Kruskall-Wallis test was carried out to examine the discriminatory ability of each descriptor selected.

\subsubsection{Sensory profile}

The sensory profiles of the three processing styles were assessed in 15 samples using the sensory profile sheet developed by the trained panel in the previous step. Three sessions of 1 hour (4-5 samples/session) were conducted to complete the analysis. Sample preparation, serving and tasting procedures were also established (GalánSoldevilla and Ruiz Pérez-Cacho 2010). The appearance attributes were assessed by the whole panel on the complete sample before carrying out the tasting. Next, in each sample, first the odor was evaluated, then the flavor (aromas, basic tastes, and trigeminal sensations) and, finally, the texture attributes. The evaluation of the odor was made by direct aspiration of the air over the tasting glass in 2 phases: first with the glass kept still to detect any possible defects, and then after shaking it gently to determine the different odor attributes.

Data analysis was carried out with the Statistical Analysis System 9.2. (SAS Institute Inc., Cary, NC, USA) and an SPSS 17.A mixed of Nested Design ANOVA and Factorial ANOVA $($ Xijk $=$ Processing style + Sample (processing style) + Assessor + (Assessor x Processing style) were used to evaluate the sensory profile data. Duncan's post hoc test was applied to detect significant differences among the samples. A canonical analysis was used to group similar samples within each processing style in order to define the sensory profile of Aloreña olives.

\subsubsection{Assessors}

Nine (3 male, 6 female) highly trained panelists from the Sensory Laboratory at Córdoba University, (Spain), aged 27 to 55 , participated in this study. The Assessors were selected and trained following international standards (ISO 1985; ISO 1993; ISO 2003; ISO 2008). The selection of assessors was based on detection, recognition and discrimination tests and on the ability of candidates to memorize and communicate sensory impressions (PerezCacho et al., 2005). These panelists had completed $300 \mathrm{~h}$ of basic training in all aspects of sensory analysis and had prior experience in the quantitative descriptive analysis of different products (GalanSoldevilla et al., 2005; Pérez-Cacho et al., 2005; 
Pérez-Cacho et al., 2008). In addition, the panel had undergone 15 hours of specific training in table-olives.

\subsubsection{Sensory laboratory}

Testing was carried out in the sensory laboratory located at the University of Córdoba (Córdoba, Spain), equipped with a round table for training sessions and individual booths, in accordance with the international standards (ISO 2007).

\section{RESULTS AND DISCUSSION}

\subsection{Generation and selection of sensory attributes}

The sensory terms were generated individually by the assessors in the tasting booths using the "unguided free selection" technique (Damasio and Costell, 1991; Guerrero, 1996; Montouto-Graña et al., 2002; Pérez-Cacho et al., 2005). Next, the panel leader held a discussion to come to an agreement on the descriptors and a consensus lexicon was developed. The initial working list (Table 1) included 59 terms: 3 for appearance, 24 for odor, 27 for flavor and 5 for texture attributes.

In the following panel sessions (round-table method), the initial working list was reduced in accordance with international standards (ISO 1994). Firstly, the appearance attributes were excluded from the analysis because they would be qualitatively assessed by the whole panel on the complete sample before carrying out the tasting. Next, the 19 negative odor/aroma attributes were omitted from the initial list because they did not describe the product. In addition, some odor/aroma descriptors were grouped in a single term: ripe fruit and green fruit as fruit and spices/herbs and fresh

Table 1

Preliminary descriptors developed in the lexicon generation for Aloreña table olives

\begin{tabular}{|c|c|c|c|c|c|}
\hline Appearance & Odor & Aroma & $\begin{array}{l}\text { Basic } \\
\text { tastes }\end{array}$ & $\begin{array}{l}\text { Trigeminal } \\
\text { sensations }\end{array}$ & Texture \\
\hline & Positive attributes & Positive attributes & & & \\
\hline Hue & Green fruit & Green fruit & Salty & Astringent & Firmness \\
\hline Luminance & Ripen fruit & Ripen fruit & Acid & Pungent & Crunchy \\
\hline \multirow[t]{23}{*}{ Uniformity of color } & Green & Spices/herbs & Bitter & Piquant & Fibrous \\
\hline & Spices/herbs & Fresh vegetable & & Fresh & Floating stone \\
\hline & Fresh vegetable & Green pepper & & & Separation of peel \\
\hline & Green pepper & Red pepper & & & \\
\hline & Red pepper & Garlic & & & \\
\hline & Garlic & Fennel & & & \\
\hline & Fennel & Thyme & & & \\
\hline & Thyme & Wood & & & \\
\hline & Lactic & Olive oil & & & \\
\hline & Hay & & & & \\
\hline & Wood & & & & \\
\hline & Olive oil & & & & \\
\hline & Negative attributes & Negative attributes & & & \\
\hline & Musty/humid & Musty/humid & & & \\
\hline & Winey/vinegary & Winey/vinegary & & & \\
\hline & $\begin{array}{l}\text { Alpechin/vegetable } \\
\text { water }\end{array}$ & $\begin{array}{l}\text { Alpechin/vegetable } \\
\text { water }\end{array}$ & & & \\
\hline & Fermentation & Fermentation & & & \\
\hline & Alcohol & Rancid & & & \\
\hline & Rancid & Rancid butter & & & \\
\hline & Rancid butter & Soap & & & \\
\hline & Soap & Lupin & & & \\
\hline & Lupin & Burnt tire & & & \\
\hline & Burnt tire & & & & \\
\hline
\end{tabular}


Table 2

Sensory attributes and references developed for Aloreña table-olives

\begin{tabular}{|c|c|c|}
\hline Sensory attribute & Definition & References \\
\hline Fruity odor/aroma & $\begin{array}{l}\text { Odor/aroma characteristic of fresh olives, } \\
\text { either ripe or unripe. }\end{array}$ & Extra virgin olive oil from Aloreña variety \\
\hline Green odor & $\begin{array}{l}\text { Odor/aroma characteristic of newly cut } \\
\text { grass }\end{array}$ & $\begin{array}{l}1 \text { drop of cis-3-hexen-1-ol in } 50 \mathrm{ml} \text { of water or } \\
\text { newly cut grass }\end{array}$ \\
\hline Seasoning odor/aroma & $\begin{array}{l}\text { Odor/aroma characteristic of spices and } \\
\text { herbs added to the Aloreña }\end{array}$ & $\begin{array}{l}\text { Mixture of spices used in seasoning of } \\
\text { Aloreña olives }\end{array}$ \\
\hline $\begin{array}{l}\text { Green pepper odor/ } \\
\text { aroma }\end{array}$ & $\begin{array}{l}\text { Odor/aroma characteristic of fresh green } \\
\text { pepper }\end{array}$ & Fresh green pepper \\
\hline Red pepper odor/aroma & Odor/aroma characteristic fresh red pepper & Fresh red pepper \\
\hline Garlic odor/aroma & Odor/aroma characteristic of fresh garlic & Fresh garlic \\
\hline Fennel odor/aroma & Odor/aroma characteristic of fresh fennel & Fresh fennel \\
\hline Thyme odor/roma & Odor/aroma characteristic of fresh thyme & Fresh thyme \\
\hline Wood odor/aroma & Odor/aroma characteristic of wood & Wood shaving in $60 \mathrm{ml}$ flask \\
\hline Hay odor & Odor of dried grass & Dried grass wrapped in aluminum paper \\
\hline Lactic odor & Odor characteristic of lactic acid & Yoghurt \\
\hline Olive oil odor/aroma & $\begin{array}{l}\text { Aroma characteristic of fresh oil from olive } \\
\text { perceived through the back of the nose. }\end{array}$ & Extra virgin olive oil from Aloreña variety \\
\hline Salty & $\begin{array}{l}\text { Basic taste produced by aqueous solutions } \\
\text { of substances like sodium chloride }\end{array}$ & $\begin{array}{l}2 \mathrm{~g} \text { of salt is dissolved in } 1 \text { liter of water. } 30 \mathrm{ml} \\
\text { of dissolution in } 50 \mathrm{ml} \text { plastic cup }\end{array}$ \\
\hline Bitter & $\begin{array}{l}\text { Basic taste produced by diluted aqueous } \\
\text { solutions of caffeine }\end{array}$ & $\begin{array}{l}0.3 \mathrm{~g} \text { of caffeine is dissolved in } 1 \text { liter of water. } \\
30 \mathrm{ml} \text { of dissolution in } 50 \mathrm{ml} \text { plastic cup }\end{array}$ \\
\hline Acid & $\begin{array}{l}\text { Basic taste produced by aqueous solutions } \\
\text { of substances like citric acid. }\end{array}$ & $\begin{array}{l}0.3 \mathrm{~g} \text { of citric acid is dissolved in } 1 \text { litter of } \\
\text { water. } 30 \mathrm{ml} \text { of dissolution in } 50 \mathrm{ml} \text { plastic cup }\end{array}$ \\
\hline Astringent & $\begin{array}{l}\text { Complex sensation accompanied by } \\
\text { shrinking of the skin of mucosa surface in } \\
\text { the mouth, produced by substances such } \\
\text { as kaki tannins }\end{array}$ & A piece of kaki \\
\hline Pungent & $\begin{array}{l}\text { Causing a sharp sensation of the nasal } \\
\text { mucosa membranes }\end{array}$ & Vinegar of wine \\
\hline Piquant & $\begin{array}{l}\text { Causing a sharp sensation of the buccal } \\
\text { mucosa membranes }\end{array}$ & Virgin oil from the Picual olive variety \\
\hline Fresh & $\begin{array}{l}\text { Sensation of reduced temperature } \\
\text { experienced as a result of exposure to } \\
\text { certain substances such as menthol or } \\
\text { anise. }\end{array}$ & $\begin{array}{l}\text { Sensation perceived during mastication of } \\
\text { fennel (leaves). }\end{array}$ \\
\hline Firmness & $\begin{array}{l}\text { Mechanical property of texture related to } \\
\text { the strength required to attain a certain } \\
\text { penetration of the olive. }\end{array}$ & Gordal olive with stone \\
\hline Crunchy & $\begin{array}{l}\text { Mechanical property of texture related to } \\
\text { the cohesion and strength necessary to } \\
\text { break an olive with the teeth. }\end{array}$ & Gordal olive with stone \\
\hline Fibrous & $\begin{array}{l}\text { Geometrical property of texture related to } \\
\text { the perception of strands oriented in the } \\
\text { same direction }\end{array}$ & A portion of celery \\
\hline Floating stone & $\begin{array}{l}\text { Aloreña variety conserves its stone intact } \\
\text { and is attached to the stalk. }\end{array}$ & Aloreña olive-table \\
\hline $\begin{array}{l}\text { Separation of peel } \\
\text { during mastication }\end{array}$ & $\begin{array}{l}\text { Texture attribute that evaluates the } \\
\text { separation of the olive peel during } \\
\text { mastication }\end{array}$ & Aloreña olive-table \\
\hline
\end{tabular}


vegetable as seasoning, resulting in 33 attributes. The sensory attributes, definitions and references are shown in Table 2. Generally, the descriptors resulting from the preliminary generation are numerous and many of them are later discarded on the basis of being vague, redundant, quantitative, synonyms, antonyms or non-discriminating terms (Stone and Sidel, 1993; ISO, 1994; Barcenas et al., 1999; Drake et al., 2001; Galán-Soldevilla et al., 2005; Pérez-Cacho et al., 2005; Retiveau et al., 2005; Riu-Amatell et al., 2008; Talavera-Bianchi and Chambers, 2008; Drake et al., 2010).

According to ISO (1994), to reduce the number of attributes and determine the most significant among them, each term was evaluated using a scale ranging from one (very slight perception) to five (very intense), and zero (0) equivalent to an absence of perception for the attribute considered (ISO 1994). Next, the tasting list was made up and 14 descriptors were rejected before the PCA analysis: 3 had the same intensity in all the samples (fibrous, floating stone and separation of peel during mastication), 7 had low number of mentions (olive oil odor, red pepper odor/aroma, fennel odor/aroma and thyme odor/aroma) and 4 were grouped (garlic odor/aroma and green pepper odor/aroma) within the "seasoning" term. It is worth mentioning that the seasoning odor and aroma are strongly influenced by the garlic or by green pepper odor and aroma. Also, it should be noted that four additional terms, although previously found to be representative of the samples, were finally not perceived in any of them and they were eliminated from the list: hay odor, wood aroma, piquant and fresh (Byrne et al., 2001; Drake et al., 2001; PérezCacho et al., 2005).

PCA was then employed as a final step for selecting the attributes that best characterized the samples (ISO 1994). The resulting 15 descriptors (5 odor attributes: fruit, green, seasoning, wood and lactic; 3 aroma attributes: fruit, olive oil and seasoning; 3 basic tastes: salty, acid and bitter; 2 trigeminal attributes: astringent and pungent and 2 texture attributes: firmness and crunchy) were subjected to a PCA on the correlation matrix. A twofactor model that explains $57.7 \%$ of total variance was selected based on eigenvalue values and on the contribution of descriptors to the relevant axes. This percentage of variance explained is rather low but it allows us to select the main attributes characterizing the table olives. Other authors have found a similar percentage of variance values with sensory data (Lee et al., 2001; Riu-Aumatell et al., 2008).

Figure 1 represents the plot of the attributes on the plane defined by the first two components. The first dimension selects the main sensory attributes that define the Aloreña table-olive (fruit odor and

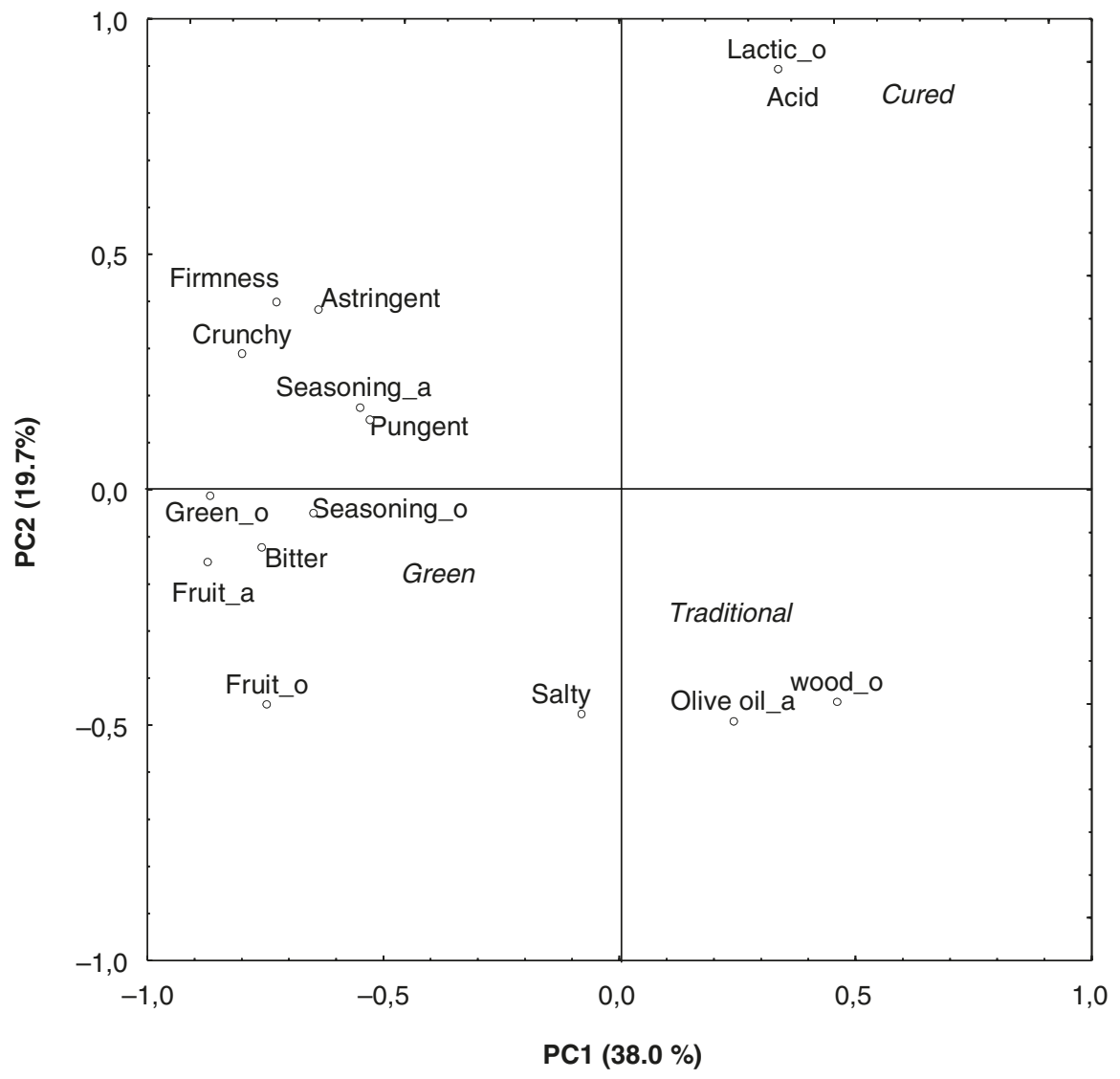

Figure 1

PCA loadings plot of the 15 terms selected by the sensory panel on the first two factors (PC1 vs. PC2). 
aroma, green odor, seasoning odor, bitter taste, firmness and crunchy) and separates the green table-olives from the rest of the processing styles on the basis of their green odor attribute. The second dimension separates the cured Aloreña table-olive from the rest of the samples by their lactic odor and acid taste. Thus, Figure 2 shows the score plot for the table-olive samples using the first two factors: the first group is composed of green Aloreña olive samples $(1,4,6,7,10,12$ and 14), the second group is formed by traditional olive samples $(2,3,5$, 8,9 and 13) and the third group is composed of the cured sample (11).

For the selection of descriptive attributes, factor loading values on both factors were taken into account together (Table 3). In this study, those terms not showing a high discriminatory power were rejected, unless their quality of representation was high (values of over 0.65). Thus, 9 descriptors were maintained to characterize Aloreña tableolives: 4 for odor (fruit, green, seasoning and lactic), 1 for aroma (fruit), 2 for basic tastes (acid and bitter) and 2 for texture (firmness and crunchy). The Kruskall-Wallis test indicated that all attributes selected significantly discriminated among samples $(p<0.001)$. Finally, 4 attributes were added by the panel in a round-table discussion in order to achieve a better characterization of the Aloreña table-olives in accordance with ISO (1994): overall odor intensity, overall aroma intensity, seasoning aroma and piquant.

If we compare our findings with other research works, it is observed that although there are many works dealing with the sensory characterization of extra virgin olive oils, there are very few related to table olives (Kanavouras et al., 2005; Panagou et al., 2006; Gonzalez et al., 2007; Marsilio et al., 2008; Aponte et al., 2010; Lanza et al., 2010; Valencic et al., 2010). What is more, those works only give information on the appearance (color), texture (firmness) and basic tastes (salty, acid and bitter) and not on the odor/aroma attribute characterizing them. However, the International Olive Council has recently published a method for the sensory assessment of table-olives in order to classify them into commercial categories (IOOC, 2008). This document proposes some odor defects that agree with our sensory findings (abnormal fermentation, musty, rancid or winey-vinegary) but not positive odor and aroma attributes.

\subsection{Sensory profile}

The results of the ANOVA carried out on the samples are reported in Table 4. Green odor, lactic odor and acid taste are not included in this analysis because the green odor attribute is only evaluated for the green olives and the other 2 attributes for the cured ones. The effect of the factor processing style was significant only for three descriptors: fruit odor, bitter taste and firmness $(p<0.05)$ whereas the effect of the samples nested in each processing style was significant for all the attributes $(p<0.001)$. There was no significant differences among the assessors except for overall odor intensity and seasoning aroma $(p<0.05)$. For the (assessors $x$ processing style) interaction effect, representing the panel's performance, 4 attributes out of 10 were

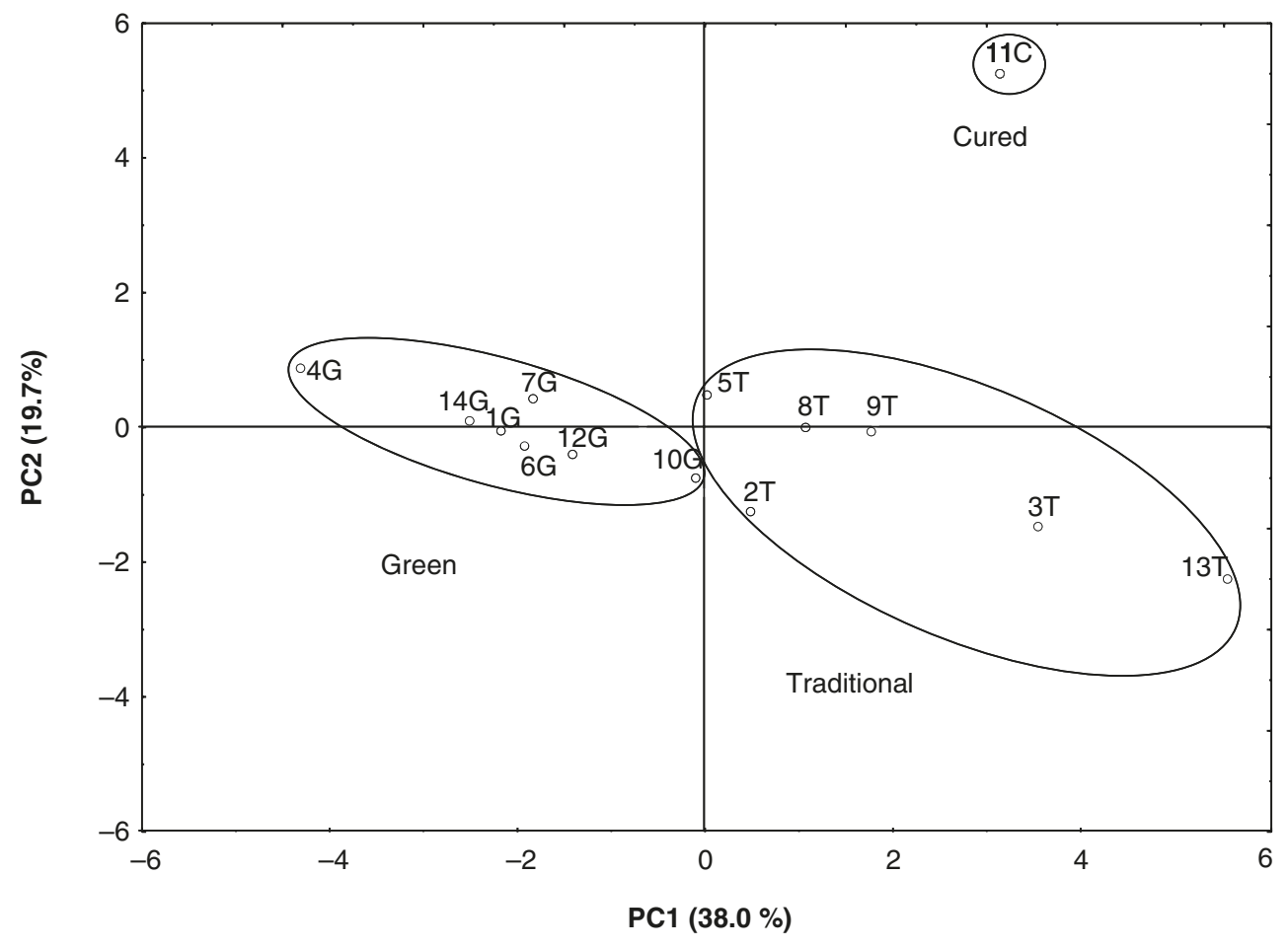

Figure 2

PCA score plot of table-olives using the first two factors (PC1 vs. PC2) obtained from the PCA by the sensory panel. 
Table 3

Loadings on the first two dimensions of PCA on the correlation matrix

\begin{tabular}{lrr}
\hline & Factor $\mathbf{1}$ & Factor 2 \\
\hline Fruit_o & $-0,746647$ & $-0,457762$ \\
Green_o & $-0,864435$ & $-0,015482$ \\
Seasoning_o & $-0,645813$ & $-0,052511$ \\
wood_o & 0,465849 & $-0,453082$ \\
Lactic_o & 0,337687 & 0,890799 \\
Hardness & $-0,725660$ & 0,396970 \\
Crunchy & $-0,797972$ & 0,284669 \\
Bitter & $-0,757340$ & $-0,122927$ \\
Salty & $-0,076766$ & $-0,479144$ \\
Acid & 0,339569 & 0,891561 \\
Fruit_a & $-0,870473$ & $-0,158639$ \\
Olive oil_a & 0,246646 & $-0,493226$ \\
Seasoning_a & $-0,545734$ & 0,173156 \\
Astringent & $-0,636097$ & 0,379105 \\
Pungent & $-0,524271$ & 0,146915 \\
\hline
\end{tabular}

significantly different: odor intensity, seasoning odor, aroma intensity and seasoning aroma. It is worth mentioning that the odor and aroma intensities are strongly influenced by the seasoning odor and aroma. The main sensory differences among the three processing styles were due to a loss in the green odor/aroma notes in traditional and cured olives and the development of lactic odor and an acid taste in the cured olives. In addition, the data showed a decrease in the intensity values of fruit odor and aroma, bitter taste and firmness from the green to the cured olives. These results could be related to the manufacturing process: olives are kept in brine until their delivery when they are seasoned, developing a lactic fermentation over a more or less variable period of time (a minimum of 3 days at a refrigeration temperature for green olives, a minimum of 20 days at room temperature for traditional ones and a minimum of 90 days for cured ones). ANOVA analysis also indicated that there were differences between samples for all the attributes within each processing style and it was due to the way that they were prepared as well.

Duncan's post hoc test was applied to detect significant differences among the samples (Tables 5, 6 and 7) and the data showed that all samples were different within each processing style. Next, a canonical analysis was used to group similar samples within each processing style in order to define their sensory profiles (Figure 3-5). For green olive samples, the first two functions $(79.7 \%$ of total variability) joined samples in four different groups: samples 1, 4 and 5; sample 2; sample 3; and samples 6 and 7 . For traditional olive samples, all the samples were independent groups $(83.6 \%$ of total variability) and for the cured one (96.6\%
Table 4

Nested Design ANOVA and Factorial. $F$ and probability values

\begin{tabular}{|c|c|c|c|}
\hline Attributes & Factor & $\mathbf{F}$ & $p$ \\
\hline Intensity_o & $\begin{array}{l}\text { Style } \\
\text { Sample (style) } \\
\text { Assessor } \\
\text { Style x Assessor }\end{array}$ & $\begin{array}{r}2.31 \\
103.34 \\
3.12 \\
2.70\end{array}$ & $\begin{array}{l}0.1421 \\
0.0001 \\
0.0141 \\
0.0084\end{array}$ \\
\hline Fruit_o & $\begin{array}{l}\text { Style } \\
\text { Sample (style) } \\
\text { Assessor } \\
\text { Style x Assessor }\end{array}$ & $\begin{array}{r}7.68 \\
113.40 \\
1.12 \\
1.76\end{array}$ & $\begin{array}{l}0.0071 \\
0.0001 \\
0.3607 \\
0.0885\end{array}$ \\
\hline Seasoning_o & $\begin{array}{l}\text { Style } \\
\text { Sample (style) } \\
\text { Assessor } \\
\text { Style x Assessor }\end{array}$ & $\begin{array}{r}3.14 \\
70.75 \\
1.06 \\
3.81\end{array}$ & $\begin{array}{l}0.0801 \\
0.0001 \\
0.3925 \\
0.0005\end{array}$ \\
\hline Intensity_a & $\begin{array}{l}\text { Style } \\
\text { Sample (style) } \\
\text { Assessor } \\
\text { Style x Assessor }\end{array}$ & $\begin{array}{r}0.79 \\
86.38 \\
1.65 \\
2.29\end{array}$ & $\begin{array}{l}0.4765 \\
0.0001 \\
0.1617 \\
0.0235\end{array}$ \\
\hline Fruit_a & $\begin{array}{l}\text { Style } \\
\text { Sample (style) } \\
\text { Assessor } \\
\text { Style x Assessor }\end{array}$ & $\begin{array}{r}0.51 \\
115.90 \\
0.32 \\
0.35\end{array}$ & $\begin{array}{l}0.6144 \\
0.0001 \\
0.9000 \\
0.9622\end{array}$ \\
\hline Seasoning_a & $\begin{array}{l}\text { Style } \\
\text { Sample (style) } \\
\text { Assessor } \\
\text { Style x Assessor }\end{array}$ & $\begin{array}{r}0.46 \\
135.65 \\
2.52 \\
2.87\end{array}$ & $\begin{array}{l}0.6426 \\
0.0001 \\
0.0392 \\
0.0054\end{array}$ \\
\hline Bitter & $\begin{array}{l}\text { Style } \\
\text { Sample (style) } \\
\text { Assessor } \\
\text { Style x Assessor }\end{array}$ & $\begin{array}{r}36.14 \\
50.26 \\
1.25 \\
1.57\end{array}$ & $\begin{array}{l}0.0001 \\
0.0001 \\
0.2099 \\
0.1113\end{array}$ \\
\hline Piquant & $\begin{array}{l}\text { Style } \\
\text { Sample (style) } \\
\text { Assessor } \\
\text { Style x Assessor }\end{array}$ & $\begin{array}{r}3.04 \\
84.07 \\
0.26 \\
0.70\end{array}$ & $\begin{array}{l}0.0854 \\
0.0001 \\
0.9332 \\
0.7230\end{array}$ \\
\hline Crunchy & $\begin{array}{l}\text { Style } \\
\text { Sample (style) } \\
\text { Assessor } \\
\text { Style x Assessor }\end{array}$ & $\begin{array}{r}1.39 \\
22.14 \\
0.64 \\
1.73\end{array}$ & $\begin{array}{l}0.2863 \\
0.0001 \\
0.6671 \\
0.0953\end{array}$ \\
\hline Firmness & $\begin{array}{l}\text { Style } \\
\text { Sample (style) } \\
\text { Assessor } \\
\text { Style x Assessor }\end{array}$ & $\begin{array}{r}4.77 \\
25.50 \\
1.33 \\
1.62\end{array}$ & $\begin{array}{l}0.0299 \\
0.0001 \\
0.2641 \\
0.1217\end{array}$ \\
\hline
\end{tabular}

of total variability), samples were grouped into three batches: sample 12; samples 13 and 14; and sample 15.

Finally, the panel evaluations of the appearance of the olive samples showed that the fresh green ones had a light green coloring, the traditional ones a straw yellow one and the cured ones were brown.

Therefore, green olives were characterized by their green color, odor and aroma of green, fruit and seasoning, their bitter taste and firm and crunchy texture. The main differences observed between the four different sensory profiles were due to the intensity values of fruit and seasoning 
Table 5

Green olive mean sensory scores and corresponding Duncan's significant difference at $\mathbf{p} \leq \mathbf{0 . 0 5}$

\begin{tabular}{lccccccc}
\hline \multicolumn{1}{c}{ Attribute } & Sample 1 & Sample 2 & Sample 3 & Sample 4 & Sample 5 & Sample 6 & Sample 7 \\
\hline Odor intensity & $6.4 \mathrm{a}$ & $7.1 \mathrm{~b}$ & $7.1 \mathrm{~b}$ & $6.5 \mathrm{c}$ & $6.4 \mathrm{a}$ & $6.3 \mathrm{a}$ & $6.2 \mathrm{a}$ \\
Fruit odor & $6.1 \mathrm{a}$ & $7.2 \mathrm{~b}$ & $3.8 \mathrm{c}$ & $6.9 \mathrm{~d}$ & $4.8 \mathrm{e}$ & $6.4 \mathrm{af}$ & $6.4 \mathrm{f}$ \\
Green odor & $1.8 \mathrm{a}$ & $2.7 \mathrm{~b}$ & $1.7 \mathrm{a}$ & $2.0 \mathrm{ac}$ & $2.1 \mathrm{c}$ & $2.0 \mathrm{ac}$ & $2.7 \mathrm{~b}$ \\
Seasoning odor & $6.5 \mathrm{a}$ & $7.3 \mathrm{~b}$ & $7.2 \mathrm{~b}$ & $6.3 \mathrm{ac}$ & $6.5 \mathrm{a}$ & $6.4 \mathrm{a}$ & $6.1 \mathrm{c}$ \\
Aroma intensity & $5.3 \mathrm{a}$ & $6.7 \mathrm{~b}$ & $6.9 \mathrm{~b}$ & $5.2 \mathrm{ac}$ & $4.9 \mathrm{c}$ & $6.2 \mathrm{~d}$ & $5.8 \mathrm{e}$ \\
Fruit aroma & $3.5 \mathrm{a}$ & $5.7 \mathrm{~b}$ & $2.7 \mathrm{c}$ & $2.9 \mathrm{~d}$ & $3.7 \mathrm{e}$ & $6.2 \mathrm{f}$ & $5.3 \mathrm{~g}$ \\
Seasoning aroma & $5.6 \mathrm{a}$ & $6.7 \mathrm{~b}$ & $6.7 \mathrm{~b}$ & $5.1 \mathrm{c}$ & $5.3 \mathrm{c}$ & $3.7 \mathrm{~d}$ & $4.5 \mathrm{e}$ \\
Bitter & $6.2 \mathrm{a}$ & $7.2 \mathrm{~b}$ & $7.3 \mathrm{~b}$ & $6.2 \mathrm{a}$ & $5.4 \mathrm{c}$ & $6.9 \mathrm{~d}$ & $6.4 \mathrm{a}$ \\
Piquant & $4.0 \mathrm{a}$ & $6.4 \mathrm{~b}$ & $3.8 \mathrm{ad}$ & $1.8 \mathrm{c}$ & $3.0 \mathrm{~d}$ & $3.0 \mathrm{~d}$ & $3.4 \mathrm{~d}$ \\
Crunchy & $7.0 \mathrm{a}$ & $6.3 \mathrm{bd}$ & $7.4 \mathrm{a}$ & $6.0 \mathrm{~b}$ & $6.8 \mathrm{ad}$ & $7.0 \mathrm{ad}$ & $5.1 \mathrm{c}$ \\
Firmness & $5.2 \mathrm{a}$ & $6.2 \mathrm{~b}$ & $5.8 \mathrm{~b}$ & $4.7 \mathrm{~cd}$ & $5.1 \mathrm{ad}$ & $5.8 \mathrm{~b}$ & $4.5 \mathrm{c}$ \\
\hline
\end{tabular}

Means with the same letter are not significantly different with $p \leq 0.5$.

Table 6

Traditional olive mean sensory scores and corresponding Duncan's significant difference at $\mathrm{p} \leq \mathbf{0 . 0 5}$

\begin{tabular}{lcccc}
\hline \multicolumn{1}{c}{ Attribute } & Sample 8 & Sample 9 & Sample 10 & Sample 11 \\
\hline Odor intensity & $4.7 \mathrm{a}$ & $6.7 \mathrm{~b}$ & $5.4 \mathrm{c}$ & $5.0 \mathrm{a}$ \\
Fruit odor & $3.7 \mathrm{a}$ & $4.9 \mathrm{~b}$ & $3.7 \mathrm{a}$ & $3.2 \mathrm{c}$ \\
Seasoning odor & $4.9 \mathrm{a}$ & $6.2 \mathrm{~b}$ & $5.1 \mathrm{a}$ & $5.3 \mathrm{a}$ \\
Aroma intensity & $5.3 \mathrm{a}$ & $6.5 \mathrm{~b}$ & $5.4 \mathrm{a}$ & $3.6 \mathrm{c}$ \\
Fruit aroma & $3.3 \mathrm{ad}$ & $3.4 \mathrm{a}$ & $5.4 \mathrm{~b}$ & $2.9 \mathrm{~cd}$ \\
Seasoning aroma & $5.4 \mathrm{a}$ & $6.9 \mathrm{~b}$ & $3.1 \mathrm{c}$ & $3.3 \mathrm{c}$ \\
Bitter & $4.5 \mathrm{a}$ & $6.8 \mathrm{~b}$ & $3.7 \mathrm{c}$ & $5.2 \mathrm{~d}$ \\
Piquant & $7.5 \mathrm{a}$ & $4.6 \mathrm{~b}$ & $2.1 \mathrm{c}$ & $5.3 \mathrm{~d}$ \\
Crunchy & $6.6 \mathrm{a}$ & $6.6 \mathrm{a}$ & $7.0 \mathrm{a}$ & $5.6 \mathrm{~b}$ \\
Firmness & $3.9 \mathrm{a}$ & $4.9 \mathrm{~b}$ & $4.2 \mathrm{a}$ & $4.1 \mathrm{a}$ \\
\hline
\end{tabular}

Means with the same letter are not significantly different with $p \leq 0.5$.

Table 7

Cured olive mean sensory scores and corresponding Duncan's significant difference at $p \leq 0.05$

\begin{tabular}{lcccc}
\hline \multicolumn{1}{c}{ Attribute } & Sample 12 & Sample 13 & Sample 14 & Sample 15 \\
\hline Odor intensity & $4.0 \mathrm{a}$ & $6.4 \mathrm{~b}$ & $6.6 \mathrm{~b}$ & $7.0 \mathrm{c}$ \\
Fruit odor & $2.2 \mathrm{a}$ & $4.4 \mathrm{~b}$ & $4.6 \mathrm{~b}$ & $3.2 \mathrm{c}$ \\
Seasoning odor & $3.8 \mathrm{a}$ & $6.3 \mathrm{~b}$ & $6.4 \mathrm{~b}$ & $7.0 \mathrm{c}$ \\
Lactic odor & $2.2 \mathrm{a}$ & $2.3 \mathrm{a}$ & $3.0 \mathrm{~b}$ & $1.5 \mathrm{c}$ \\
Aroma intensity & $4.9 \mathrm{a}$ & $6.1 \mathrm{~b}$ & $6.1 \mathrm{~b}$ & $6.2 \mathrm{~b}$ \\
Fruit aroma & $1.9 \mathrm{a}$ & $4.6 \mathrm{~b}$ & $4.4 \mathrm{~b}$ & $3.1 \mathrm{c}$ \\
Seasoning aroma & $4.3 \mathrm{a}$ & $6.0 \mathrm{~b}$ & $5.1 \mathrm{c}$ & $6.2 \mathrm{~b}$ \\
Bitter & $2.6 \mathrm{a}$ & $2.0 \mathrm{bc}$ & $2.5 \mathrm{ac}$ & $1.8 \mathrm{~b}$ \\
Acid & $2.0 \mathrm{a}$ & $3.5 \mathrm{~b}$ & $4.0 \mathrm{c}$ & $2.0 \mathrm{a}$ \\
Piquant & $2.9 \mathrm{a}$ & $1.6 \mathrm{~b}$ & $1.8 \mathrm{~b}$ & $2.5 \mathrm{c}$ \\
Crunchy & $7.0 \mathrm{a}$ & $5.9 \mathrm{~b}$ & $5.1 \mathrm{c}$ & $5.1 \mathrm{c}$ \\
Firmness & $5.2 \mathrm{a}$ & $3.8 \mathrm{~b}$ & $3.6 \mathrm{~b}$ & $4.8 \mathrm{c}$ \\
\hline
\end{tabular}

Means with the same letter are not significantly different with $p \leq 0.5$ 


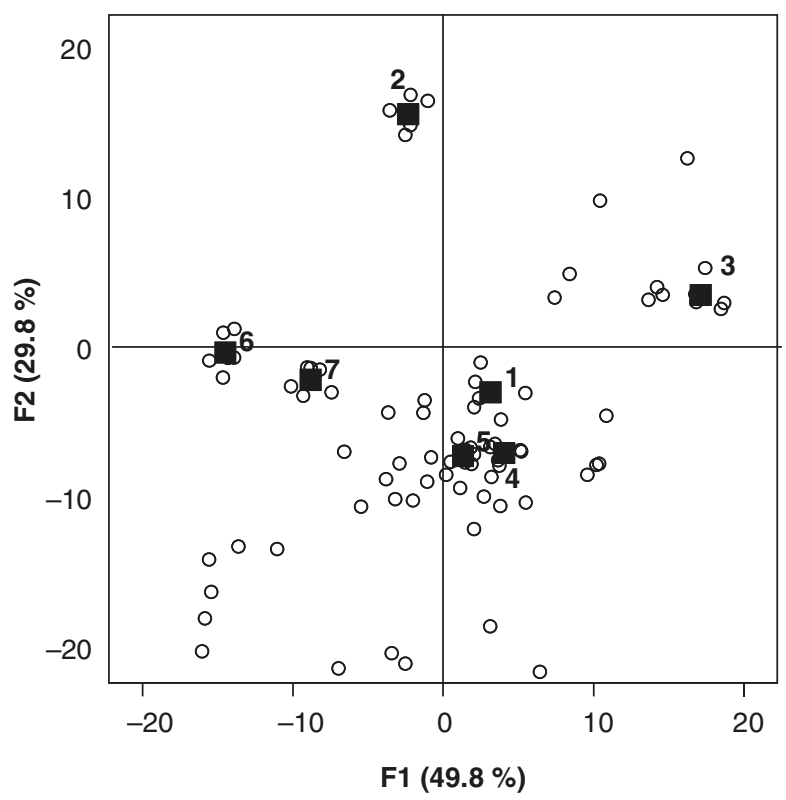

Figure 3

Scores on the first two canonical functions for the green olive samples

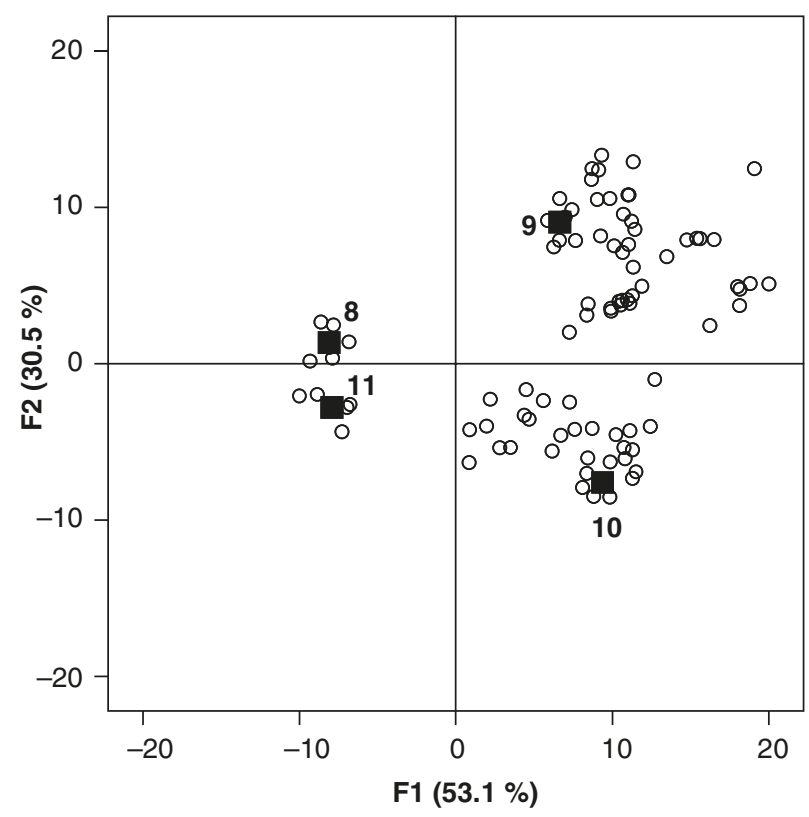

Figure 4

Scores on the first two canonical functions for the traditional olive samples.

odor/aroma and piquant attributes (Table 5 and Figure 3). The traditional ones were characterized by having a straw yellow color, fruity and seasoning odor and aroma, a bitter taste and a firm and crunchy texture. The main sensory differences among samples were due to the intensity values of fruit and seasoning odor/aroma, bitter taste and piquant attribute (Table 6 and Figure 4). It is worth mentioning that traditional samples show a decrease in their fruit odor/aroma and their bitter taste intensity values from the beginning until the end of the growing season. Cured olives develop a deep lactic fermentation, acquiring a lactic odor

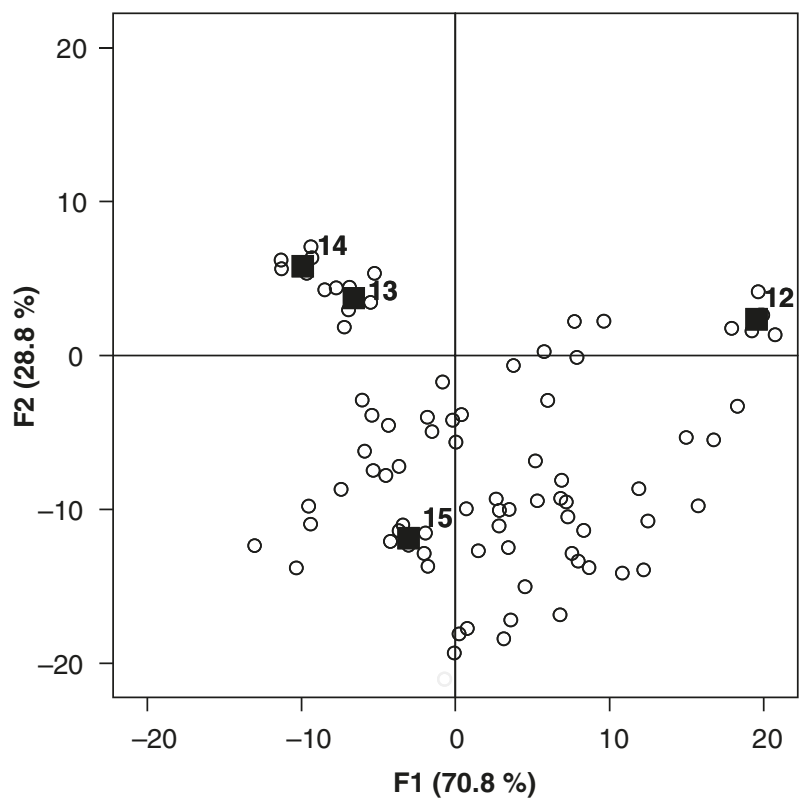

Figure 5

Scores on the first two canonical functions for the cured olive samples.

and an acid taste. The differences observed among the three different groups of samples were due to the intensity values of the fruit and seasoning odor/ aroma, lactic odor, piquant and crunchy and firm texture (Table 7 and Figure 5).

It worth mentioning that Aloreña olives are marketed until perceptible sensory defects appear. It is important to highlight the large number of traditional samples presenting sensory defects which were clearly perceptible to the panel. This was due to the way that they were prepared as the olives were kept in brine with no refrigeration, with their sensory profile evolving throughout the season, losing their fruity and green odor attributes and bitter taste and with defects appearing over time. Different alternative storage systems for preventing such changes and preserving the freshness of the olive fruits are being studied (Arroyo-López et al., 2007; Arroyo-López et al., 2008a; Arroyo-López et al., 2008b; Arroyo-López et al., 2009).

\section{CONCLUSIONS}

A sensory lexicon and its standard references were developed by a trained panel. The lexicon provided will help researchers to describe the sensory characteristics of other olive varieties and can be of considerable benefit to olives producers.

\section{ACKNOWLEDGEMENTS}

Special thanks go to the UCO sensory panel members for their voluntary participation and to Professor Andrés Muñoz Serrano for the statistical analysis. We express our gratitude to "Grupo 
de Desarrollo Rural Valle del Guadalhorce", Málaga (Spain) for providing funds to conduct this research project. We should also like to thank the local commercial producers in the area for their participation in the panel.

\section{REFERENCES}

Aponte M, Ventorino V, Blaiotta G, Volpe G, Farina V, Avellone G, Lanza MC, Moschetti G. 2010. Study of green Sicilian table olive fermentations through microbiological, chemical and sensory analyses. Food Microbiol. 27, 162-170.

Arroyo-Lopez FN, Duran-Quintana MC, Romero, C, Rodriguez-Gomez F, Garrido-Fernandez A. 2007. Effect of storage process on the sugars, polyphenols, color and microbiological changes in cracked Manzanilla-aloreña table olives. J. Agric. Food Chem. 55, 7434-7444.

Arroyo-López FN, Bautista-Gallego J, Durán-Quintana MC, Rodríguez-Gómez F, Romero-Barranco C., Garrido-Fernández A 2008a. Improvement of the storage process for cracked table olives. J. Food Eng. 89, 479-487.

Arroyo-López FN, Bautista-Gallego J, Durán-Quintana MC, Garrido-Fernández A. 2008b. Effects of ascorbic acid, sodium metabisulfite and sodium chloride on freshness retention and microbial growth during the storage of Manzanilla-Aloreña cracked table olives. LWT-Food Sci. Technol. 41, 551-560.

Arroyo-López FN, Bautista-Gallego J, Segovia-Bravo KA, García-García P, Durán Quintana MC, Romero C, Rodrıguez-Gomez F, Garrido-Fernandez A. 2009. Instability profile of fresh packed "seasoned" Manzanilla-Aloreña table olives. LWT-Food Sci Technol. 42, 1629-1639.

Barcenas P, Elortondo FJP, Salmeron J, Albisu M. 1999. Development of a preliminary sensory lexicon and standard references of ewes milk cheeses aided by multivariate statistical procedures. J. Sens. Stud. 14, 131-79.

BOJA número 215, 11 de abril de 2009. Orden de 26 de octubre de 2009, por la que se aprueba el Reglamento de la Denominación de Origen Protegida «Aceituna Aloreña de Málaga» y de su Consejo Regulador.

Byrne DV, O'sullivan MG, Dijksterhuis GB, Bredie WLP, Martens M. 2001. Sensory panel consistence during development of a vocabulary for warned-over flavour. Food Qual. Prefer. 12, 171-87.

Damasio MH, Costell E. 1991. Descriptive sensory analysis-Generation of descriptors and selection of judges. Rev. Agro. Tec. Alim. 31, 165-78.

Drake MA, Mclngvale SC, Gerard PD, Cadwallader KR, Civille GV. 2001. Development of a descriptive language for cheddar cheese. J. Food Sci. 66, 142227.

Drake SL, Yates MD, Drake MA. 2010. Development of a flavor lexicon for processed and imitation cheeses. J. Sens. Stud. 25,720-39.

Galán-Soldevilla $H$, Ruiz Pérez-Cacho $P$, Jiménez $S$, Villarejo M, Manzanares AB. 2005. Deveopment of a preliminary sensory lexicon for floral honey. Food Qual Prefer. 16, 71-7

Galán-Soldevilla H, Ruiz Pérez-Cacho P. 2010. Sensory characterization of Aloreña olives Universidad de Córdoba (Córdoba-Spain). Private report to the Manzanilla-Aloreña industrial sector.
González M, Navarro T, Gómez G, Pérez R, Lorenzo C. 2007. Análisis sensorial de aceitunas de mesa I: Configuración de un grupo de cata y obtención de escalas normalizadas. Grasas Aceites 58, 225-30.

Guerrero L, Gou P, Alonso P, Arnau J. 1996. Study of the physicochemical and sensorial characteristics of drycured hams in three pig genetic types. J. Sci. Food Agric. 70, 526-30.

Guerrero L. 1999. El análisis sensorial de los embutidos derivados del cerdo. In: De Castro Martín JJ, Sancho Valls J, Bota Prieto E, editors. Introducción al análisis sensorial de alimentos. Barcelona: Universitat de Barcelona. p.219-27.

IOOC Internacional Olive Oil Council. 1987. Sensory analysis of olive oil standard glass for oil tasting. Document number COI/T20/Doc no 5 . Madrid.

IOOC International Olive Oil Council. 2008. Método para el análisis sensorial de las aceitunas de mesa. Document number COI/OT/MO no 1. Madrid.

ISO 6564. 1985. Sensory analysis-methodology-flavour profile methods. (International Organization for Standardization).

ISO 8586-1.1993. General guidance for the selection training and monitoring of assessors. Part 1: selected assessors. (International Organization for Standardization).

ISO 11035. 1994. Identification and selection of descriptors for establishing a sensory profile by a multidimensional approach. (International Organization for Standardization).

ISO 13299. 2003. General Guidance for establishing a sensory profile. (International Organization for Standardization).

ISO 8589. 2007. General guidance for the design of test rooms. (International Organization for Standardization).

ISO 5492. 2008. Vocabulary. (International Organization for Standardization).

Kanavouras A, Gazouli M, Tzouvelekis L, Petrakis C. 2005. Evaluation of black table olives in different brines. Grasas Aceites. 106, 106-15.

Lanza B, Di Serio MG, lannucci E, Russi F, Marfisi P. 2010. Nutritional, textural and sensorial characterisation of Italian table olives Olea europaea L cv 'Intosso d'Abruzzo'. Int. J. Food Sci. Technol. 45, 67-74.

Lee KYM, Paterson A, Piggott JR, Richardson GD. 2001. Sensory discrimination of blended Scotch whiskies of different product categories. Food Qual. Prefer. 12, 109-17.

Marsilio V, Russi F, lannucci E, Sabatini N. 2008. Effects of alkali neutralization with $\mathrm{CO} 2$ on fermentation chemical parameters and sensory characteristics in Spanish-style green olives Olea europaea L. LWTFood Sci. Technol. 41, 796-802.

Montouto-Graña $M$, Fernández-Fernández E, VázquezOdériz ML, Romero-Rodríguez MA. 2002. Development of a sensory profile for the specific denomination Galician potato. Food Qual. Prefer. 13, 99-106.

Panagou EZ, Tassou C, Skandamis PN. 2006. Physicochemical, microbiological and organoleptic profiles of Greek table olives from retail outlets. J. Food Prot. 69, 1732-738.

Pérez-Cacho PR, Galán-Soldevilla H, Molina Recio G, León Crespo F. 2005. Determination of the sensory attributes of a Spanish dry-cured sausage. Meat Sci. 71, 620-33.

Pérez-Cacho PR, Galán-Soldevilla H, Mahatanattawee K, Eston A, Rouseff R. 2008. Sensory lexicon for 
fresh squeezed and processed orange juices. Food Sci. Technol. Int. 14, 131-142.

Retiveau A, Chambers DH, Esteve E. 2005. Developing a lexicon for the flavor description of French cheeses. Food Qual. Prefer. 16, 517-27

Riu-Aumatell M, Vichi S, Mora-Pons M, Lopez-Tamames E, Buxaderas S. 2008. Sensory characterization of dry gins with different volatile profiles. J. Food Sci. 73, S286-93

Scintu MF, Del Caro A, Urgeghe PP, Piga C, Di Salvo R. 2010. Sensory profile development for an italian PDO Ewe's milk cheese at two different ripening times. J. Sens. Stud. 25, 577-90
Stone H, Sidel J, 1993. Sensory evaluation practices. 2nd ed. London. Academic Press Inc.

Talavera-Bianchi M, Chambers DH. 2008. Simplified lexicon to describe flavor characteristics of western European cheeses. J. Sens. Stud. 23, 468-84.

Valencic V, Mavsar DB, Bucar-Miklavcic M, Butinar B, Cadez N, Golob T, Raspor P, Mozina S. 2010. The impact of production technology on the growth of indigenous microflora and quality of table olives from Slovenian Istria. Food Technol. Biotechnol. 48, 404-10.

Recibido: $12 / 12 / 12$ Aceptado: $23 / 4 / 13$ 